\title{
Analysis of the cytotoxic effects of the fruit extract of Crescentia cujete $\mathrm{L}$.
}

\author{
Análise dos efeitos citotóxicos do extrato do fruto de Crescentia cujete L. \\ Análisis de los efectos citotóxicos del extracto de fruto de Crescentia cujete $\mathbf{L}$.
}

Received: 12/09/2021 | Reviewed: 12/14/2021 | Accept: 01/06/2022 | Published: 01/14/2022

\author{
Bruna Miranda Januário \\ ORCID: https://orcid.org/0000-0003-1547-6901 \\ Faculdade de Integração do Sertão, Brasil \\ E-mail: brunamirandaj99@gmail.com \\ Vânia Maria de Carvalho Diniz \\ ORCID: https://orcid.org/0000-0002-2897-2915 \\ Faculdade de Integração do Sertão, Brasil \\ E-mail: vaniacarvalhod@ hotmail.com \\ Pedro Erian de Andrade Barros \\ ORCID: https://orcid.org/0000-0003-4530-2398 \\ Faculdade de Integração do Sertão, Brasil \\ E-mail: pedroerian29@gmail.com \\ Viviane da Silva Lima \\ ORCID: https://orcid.org/0000-0003-2734-8851 \\ Faculdade de Integração do Sertão, Brasil \\ E-mail: immavivianne@gmail.com \\ José Israel Guerra Junior \\ ORCID: https://orcid.org/0000-0001-8656-1850 \\ Universidade Federal de Pernambuco, Brasil \\ E-mail: israel.guerra@ufpe.br \\ Gabriela Cavalcante da Silva \\ ORCID: https://orcid.org/0000-0003-3390-6645 \\ Faculdade de Integração do Sertão, Brasil \\ E-mail: gcavalcante1988@gmail.com
}

\begin{abstract}
Introduction: Over time, treatments with plant species have become more effective for the vast majority of the population, even with a vague collection of scientific research that proves their safety and effectiveness. Among these different species is the arboreal Crescentia cujete L., which is widely distributed in Northeastern Brazil. It is applied with various therapeutic purposes, from antihypertensive, analgesic, antispasmodic and some gynecological disorders. Objective: To analyze the possible cytotoxicity of the hydroalcoholic extract of the fruit. Methodology: The extract was obtained through dynamic maceration in a hydroalcoholic solution. A cytotoxicity analysis was carried out based on the methodologies of osmotic fragility and lethality against Artemia salina L. 45.32\%. Conclusion: Therefore, further research aimed at safety and possible applicability of the extract in question is encouraged.
\end{abstract}

Keywords: Crescentia cujete; Hemolysis; Brine shrimp.

\section{Resumo}

Introdução: Ao decorrer dos tempos os tratamentos com espécies vegetais se tornaram mais vigentes para a grande maioria populacional, mesmo com um vago acervo de pesquisas científicas que comprovem a segurança e eficácia dos mesmos. Entre essas diversas espécies está a Crescentia cujete L., do tipo arbóreo, detentora de grande distribuição no Nordeste brasileiro. É aplicada com várias finalidades terapêuticas desde anti-hipertensiva, analgésica, antiespasmódica e alguns distúrbios ginecológicos. Objetivo: Analisar a possível citotoxicidade do extrato hidroalcoólico do fruto. Metodologia: A obtenção do extrato se deu através de maceração dinâmica em solução hidroalcoólica. A análise de citotoxicidade ocorreu com base nas metodologias de fragilidade osmótica e letalidade frente à Artemia Salina L. Resultados: Os ensaios citotóxicos apresentaram CL50 28,75, considerando alto potencial citotóxico frente à Artemia Salina L., quanto ao percentual hemolítico, o extrato obteve 45,32 \%. Conclusão: Portanto, impulsiona-se a realização de mais pesquisas voltadas a segurança e possível aplicabilidade do extrato em questão.

Palavras-chave: Crescentia cujete; Hemólise; Artemia salina.

\section{Resumen}

Introducción: Con el tiempo, los tratamientos con especies vegetales se han vuelto más efectivos para la gran mayoría de la población, incluso con una vaga colección de investigaciones científicas que prueban su seguridad y efectividad. Entre estas diferentes especies se encuentra la arbórea Crescentia cujete L., que se distribuye ampliamente en el noreste de Brasil. Se aplica con diversas finalidades terapéuticas, desde antihipertensivo, analgésico, antiespasmódico 
y algunos trastornos ginecológicos. Objetivo: Analizar la posible citotoxicidad del extracto hidroalcohólico del fruto. Metodología: El extracto se obtuvo mediante maceración dinámica en solución hidroalcohólica. El análisis de citotoxicidad se basó en las metodologías de fragilidad osmótica y letalidad frente a Artemia Salina L. Resultados: Los ensayos citotóxicos arrojaron CL50 28,75, considerando alto potencial citotóxico frente a Artemia Salina L., con respecto al porcentaje hemolítico, el extracto obtuvo 45,32\%. Conclusión: Por lo tanto, se recomienda realizar más investigaciones destinadas a la seguridad y la posible aplicabilidad del extracto en cuestión.

Palabras clave: Crescentia cujete; Hemólisis; Artemia salina.

\section{Introduction}

The application of plants in medicinal form is one of the oldest resources, it has been following human evolution and seeking new improvements and increasingly optimized strategies and with greater possibilities for health promotion and conservation (Ramos, et al., 2020; Ferreira, et al., 2020). Brazil has one of the greatest biodiversity on the planet, accounting for around 55,000 species of plants, many of which are restricted to a certain area and in some cases popular knowledge has low levels or is even nil. However, there are data that indicate that only $5 \%$ of these plants have been studied for their chemical compounds and a smaller percentage is seen when considering the evaluation of their biological aspects (Paulo, 2016).

Faced with this vast biodiversity is the Crescentia cujete L., belonging to the Bignoniaceae family, these are characterized as shrubs, vines and arboreal, are configured as a small tree and can hold flowers with yellowish green color and fruits with a spherical shape (Araújo, 2015). Around 840 species of plants belonging to this family are recognized, and $80 \%$ of them occur in neotropical regions and almost half of these in Brazil, expressively throughout the Northeast. They hold several chemical components, including flavonoids, terpenoids and quinones, but mainly naphthoquinones and aromatic compounds (Lima, et al., 2020).

Through its considerable role in medicinal form, the genus Crescentia becomes one of the most important members of the Bignoniaceae family. Its use in popular medicine in several countries, including Brazil, is due to its role in the treatment of hypertension, diabetes, urinary problems, and may also have abortive and antimicrobial properties (Duarte, 2019). The application of tea from the leaves is therapeutically aimed at treating headaches, hypertension, treating bruises and as a diuretic (Das et al., 2014). Regarding the use of the fruit in Brazil, it is normally applied in folk medicine in treatments such as anemia, wound healing, respiratory problems, insect repellents and in some cultures it is applied as an inducer of abortion (AguierreDugua et al., 2018).

Medicinal plants have active ingredients with effects as potential as any allopathic drug, capable of interacting with other drugs and causing health complications. Finding therapies in medicinal plants, as it is easy to obtain and at low cost, has become a frequent habit, however, people generally practice this therapy based on almost genetic and intuitive knowledge, through family, friends and inhabitants of the communities to which they belong. Usually people tend to think that because it is natural, it will not cause harmful effects and that is why the problems of intoxication, drug interactions, among others arise (Vargas, 2017).

Nowadays, the free trade of these plant species is often seen in free and mass markets, most of the time scientific knowledge is vague, so its real impact, whether harmful or beneficial, has not really been confirmed (Villas-Boas, 2018). In view of this aspect and considering the development of new drugs and the scarcity of studies contemplating information on the biological activities and toxicity of the compounds present in this species, the survey of these data is of value in the process of obtaining new substances with scientifically proven medicinal activity. Through this, this work aims to promote an assessment of the possible cytotoxicity of Crescentia cujete L., thus promoting a direction for future research. 


\section{Methodology}

It was an observational, descriptive and quantitative study, where tests were carried out to measure the cytotoxic activity effects of the fruit extract of Crescentia cujete $\mathrm{L}$.

\section{Extract preparation}

The plant material obtained at Fazenda Laranjo Velho, Bom Nome, district of São José do Belmonte-PE, northeastern Brazil, in October 2019, was sent to the practical laboratories of the Sertão-FIS Integration Faculty, Serra Talhada/PE. After washing in running water, it was dried using an oven at an average temperature of $36^{\circ}-37^{\circ} \mathrm{C}$, lasting approximately 3 days. After complete removal of moisture, the fruit was crushed to pass through weighing and then the material was pulverized. Then, the extraction (10\%) was carried out through dynamic maceration in a hydroalcoholic solution at $80 \%(w / v)$ using an orbital rotary shaker at room temperature, for a period of 12 hours (Lima et al., 2020).

Then, the extract was filtered and concentrated in a rotary evaporator at reduced pressure and the residue remained in the desiccator at room temperature to remove residual moisture. At the end of this process, a pasty concentrate with a characteristic odor was obtained, thus giving rise to the crude extract.

\section{Biological Profile Analysis \\ Osmotic fragility}

The test took place in triplicate, using test tubes with $5 \mathrm{ml}$ of $0.9 \%$ sodium chloride each, plus 3 test tubes were prepared as positive control, containing only $5 \mathrm{ml}$ distilled water and $25 \mu \mathrm{L}$ of sheep's blood. Volumes obtained from a $10 \mathrm{mg} / \mathrm{mL}$ stock solution were transferred to the test tubes in order to obtain concentrations of $50 \mu \mathrm{g} / \mathrm{mL}, 100 \mu \mathrm{g} / \mathrm{mL}, 250$ $\mu \mathrm{g} / \mathrm{mL}, 500 \mu \mathrm{g} / \mathrm{mL}, 750 \mu \mathrm{g} / \mathrm{mL}, 1000 \mu \mathrm{g} / \mathrm{mL}$. After the addition of sheep blood and homogenization, the samples were kept at room temperature for $15^{\prime}$. The samples are then centrifuged at a G-force of 3500rpm for 15'. The reading of the supernatant was carried out by means of the Oleman ${ }^{\circledR}$ spectrophotometer, using a 540nm filter, zeroing it with $0.9 \%$ sodium chloride, thus obtaining the absorbance values of each sample. The hemolytic percentage was established by the absorbance of the positive control being designated as $100 \%$. The percentage was based on the formula: $\%=$ Sample Absorbance $\mathrm{x} 100 /$ Control Absorbance (Dacie et al., 1991).

\section{Cytotoxicity against Artemia Salina Leach}

Artemia salina Leach cysts were added in seawater, which were subjected to constant aeration for $24 \mathrm{~h}$ under lighting. Then, after the cysts hatch, 10 nauplii of Artemia salina were transferred to test tubes containing $5 \mathrm{ml}$ of $0.9 \%$ sodium chloride. Next, concentrations of 4,10,20,50 and $100 \mu \mathrm{g} / \mathrm{mL}$ of the hydroalcoholic extract of the leaves of C. cujete $\mathrm{L}$ were prepared. The nauplii were incubated for 24 hours in contact with the extract at the respective concentrations, and after this period of contact, the percentage of death of the nauplii was counted. LC50 data (mean lethal concentration) were expressed according to the percentage of death. This bioassay was performed in triplicate as determined by previous studies (Meyer et al., 1982; Paula et al., 2014; Silva et al., 2020).

\section{Statistical analysis}

The software used was GraphPad Prism version 8.0, in order to calculate the means, standard deviations, as well as to construct the graphs and dose-response curve. 


\section{Results and Discussion}

The $10 \%$ hydroalcoholic extract of the fruit of Crescentia cujete L., dark green in color and pasty consistency, presented an average yield percentage of $8.97 \%$ in relation to the dry weight of the crushed sample and the weight obtained after the preparation of the extract, as description in Table 1.

Table 1. Yield percentage of the hydroalcoholic extract of the fruit of Crescentia cujete L.

\begin{tabular}{rrcc}
\hline Crescentia cujete L. & Dry weight (g) & Extract weight (g) & Yield(\%) \\
Fruto & $100 \mathrm{~g}$ & $8,975 \mathrm{~g}$ & $8,97 \%$ \\
\hline
\end{tabular}

Source: Authors.

Through a more recent study, Lima et al. (2021) performed the preliminary photochemical screening that indicated the presence of classes of metabolites such as coumarins, saponins and condensed tannins. In previous studies, some bioactive compounds of Crescentia cujete have already been isolated and identified through spectrometric techniques, such as preliminary phytochemical and chromatographic screenings. It is reported by Macedo et al. (2018) that several compounds are present in the leaf extract, the main ones being naphthoquinones, glycosides, plumeride, aucubin, irioids and asperuloside. Martins and Almeida (2012) were able to observe in their study the presence of important metabolites such as organic acids, saponins, phenols and tannins.

The presence of photochemicals always needs extra attention because at the same frequency that they can be allied in the therapeutic effects they can also be harmful. Considering the need to search for new substances with therapeutic activity with applicability of use, cytotoxicity assessment tests, such as osmotic fragility, are a good tool to verify the interaction of substances with the plasma membrane of erythrocytes (Nascimento, 2016).

As shown in Graph 1, the osmotic fragility of the $C$. cujete fruit extract expressed according to the hemolytic percentage showed a value of $45.32 \%$ at the concentration of $1000 \mu \mathrm{g} / \mathrm{mL}$, which classifies it as having a high hemolytic potential (Nofiani, 2011). Another recent study carried out with hydroalcoholic extract of the leaves of Crescentia cujete Lima et al. (2021) obtained a hemolysis percentage of $60.67 \%$ at a concentration of $1000 \mu \mathrm{g} / \mathrm{mL}$, these variations can be explained by the different concentrations of phytochemicals present in different parts of the plant, other factors such as seasonality, soil and rainfall aspects can interfere. Another consideration to be observed is that the leaf extract does not report the finding of alkaloids (Lima, 2020) and in the study carried out by Martins et al. (2014) with the alcoholic extract of the fruit of the species in question, the presence of alkaloids was obtained.

Graph 1. Percentage of hemolysis of the hydroalcoholic extract of the fruit of Crescentia cujete L. at different concentrations

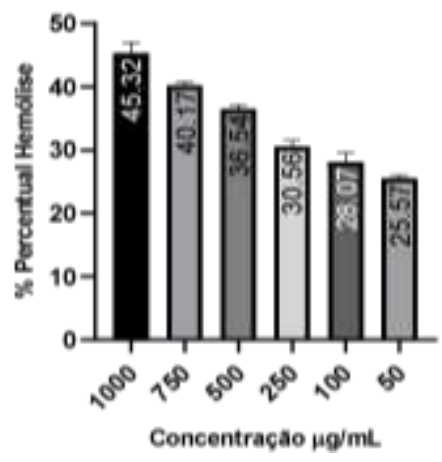

Fonte: Authors. 
Among the metabolic classes present in the extract under study, saponin is recognized in the literature for its surfactant activity capable of damaging the cell membrane. With this effect, interaction between the components of the cell membrane can occur, causing deformations in the membrane leading to the extravasation of intracellular content (Nunes, 2015). In vitro bioassays promoted against Artemia Salina are preliminarily applied in the investigation of cytotoxicity, and can also predict some biological activities such as antitumor, antibacterial and antifungal activities (Karchesy et al., 2016). According to a study published by Meyer et al. (1982) plant extracts with $\mathrm{LC}_{50}$ less than $1000 \mu \mathrm{g} / \mathrm{mL}$ have potentially toxic and/or bioactive potential. Consistent with the results shown in graph 2 , the extract presented a $\mathrm{LC}_{50}$ value corresponding to $28.75 \mu \mathrm{g} / \mathrm{mL}$, demonstrating a high degree of cytotoxicity/bioactivity.

Graph 2. Cytotoxicity of the hydroalcoholic extract of the fruit of Crescentia cujete L. against Artemia salina.

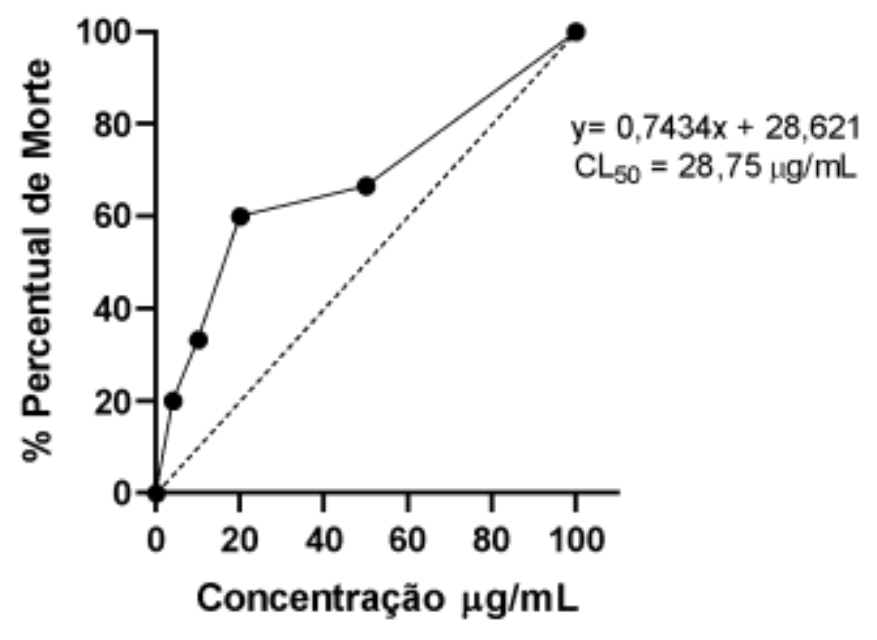

Fonte: Authors.

Cassian (2010), when evaluating the hydroalcoholic extract $20 \%$ of the root and stem of the species Tynanthus micranthus, belonging to the same family, Bignoniaceae, obtained $\mathrm{LC}_{50} 63.88 \mu \mathrm{g} / \mathrm{mL}$ and $42.99 \mu \mathrm{g} / \mathrm{mL}$, respectively. In the same sense, Viana (2015) analyzed against Artemia salina the dichloromethane extract from the stem of the species Sparattosperma leucanthum (Bignoniaceae) obtaining $\mathrm{LC}_{50} 289.4 \mu \mathrm{g} \backslash \mathrm{mL}$. Although they are from the same family, the considerably discrepant $\mathrm{LC}_{50}$ values can be justified according to the study by Paulo (2016) where the same cites that differences in cytotoxic potentials may be related to the concentration of phytochemicals, which is influenced by environmental conditions, such as seasonality, temperature, pathogen attack, maturity and other factors. Lima et al. (2021) obtained a $\mathrm{LC}_{50}$ of $1186.77 \mu \mathrm{g} / \mathrm{mL}$ in the Artemia salina bioassay, thus demonstrating low toxicity of the hydroalcoholic extract of the leaf of Crescentia cujete L., which can probably be explained by the absence or low concentration of cytotoxic phytochemicals, among others.

\section{Conclusion}

Considering the results, it can be concluded that the $\mathrm{LC}_{50}$ value obtained was considered a high cytotoxic potential, it had a high hemolytic percentage, demonstrating great interaction with plasma membranes. Although more studies are required regarding the phytochemical constitution as well as in vivo safety tests, the investigation of the preliminary biological activity of this extract may be attractive for therapeutic purposes that require cytotoxic potential. 


\section{References}

Aguirre-Dugua, X., Llanderal-Mendoza, J., González-Rodríguez, A., Eguiarte, L. E., \& Casas, A. (2018). Anthropogenic dispersion of selected germplasm creates a geographic mosaic of contrasting maternal lineages in Crescentia cujete from Mesoamerica. Tree genetics \& genomes, 14 (2), 1-16.

Araújo, A. D. L. (2015). Caracterização física, química e toxicidade do fruto do Cuité (crescentia cujete linn).

Cansian, F. C. (2011). Estudo fitoquímico e atividades biológicas da espécie Tynanthus Micranthus Corr. Méllo (Bignoniaceae).

Dacie, J. V., \& Lewis, S. M. (1995). Practical haematology. In Practical hamatology (pp. 609-609).

Das, N., Islam, M. E., Jahan, N., Islam, M. S., Khan, A., Islam, M. R., \& Parvin, M. S. (2014). Antioxidant activities of ethanol extracts and fractions of Crescentia cujete leaves and stem bark and the involvement of phenolic compounds. BMC complementary and alternative medicine, 14(1), 1-9.

Duarte, Í. L. (2019). Caracterização morfométrica e química de frutos da espécie vegetal Crescentia cujete L. em Cuité, Paraíba.

Ferreira, L. R. D., da Silva, A. F., da Silva Siqueira, J., da Conceição Santos, R., da Silva Lima, V., de Oliveira, A. M., \& da Silva, G. C. (2020). Estudo do perfil fitoquímico e avaliação dos efeitos citotóxicos do rizoma da Microgramma Vacciniifolia. Brazilian Journal of Health Review, 3(1), 1185-1202.

Karchesy, Y. M., Kelsey, R. G., Constantine, G., \& Karchesy, J. J. (2016). Biological screening of selected Pacific Northwest forest plants using the brine shrimp (Artemia salina) toxicity bioassay. Springerplus, 5(1), 1-9.

Lima, V.S., da Conceição Santos, R., Ramos, M. L. H., da Silva, R. E., do Nascimento Nunes, J. V., Ramos, R. M., \& da Silva, G. C. (2020). Aspectos fitoquímicos e potencialidades biológicas da Crescentia: uma revisão narrativa. Revista Eletrônica Acervo Saúde, 12 (9), e3886-e3886.

Lima, M. E. N., Januário, B. M., de Andrade Barros, P. E., Feitosa, J. M., da Silva Lima, V., \& da Silva, G. C. (2021). Perfil fitoquímico e avaliação do potencial citotóxico do extrato das folhas de crescentia cujete L. Research, Society and Development, 10(15), e339101522805-e339101522805.

Macedo, W., Mello, V., Santos, B. N., Fernandes, L., \& Karsburg, I. (2018). Efeito citotóxico e genotóxico de crescentia cujete 1.(bignociaceae) através do bioteste Allium cepa. Agrarian Academy, 5(10).

Martins, A. M. L.; Almeida, S. S. M. S. Estudo fitoquímico da polpa de Crescentia cujete L. (BIGNONIACEAE). Livro de resumos do $3^{\circ}$ Congresso amapaense de iniciação científica e $3^{\circ}$ Exposição de pesquisa científica. 2012.

Meyer, B. N., Ferrigni, N. R., Putnam, J. E., Jacobsen, L. B., Nichols, D. J., \& McLaughlin, J. L. (1982). Brine shrimp: a convenient general bioassay for active plant constituents. Planta medica, 45(05), 31-34.

Nascimento Junior, J. A. A. D. (2016). Avaliação do potencial antioxidante e atividade citotóxica de extrato metanólicos de plantas medicinais da caatinga (Master's thesis, Universidade Federal de Pernambuco).

Nofiani, R., Kurniadi, R., \& Ardiningsih, P. (2011). Antimicrobial, antioxidant, hemolytic activities and toxicity of ethyl acetate extract from an unidentified coral-associated Fungus, Aspergillus brevipes RK06. Indonesian Journal of Cancer Chemoprevention, 2(2), $212-216$.

Nunes, C. D. R. (2015). Estudo químico e avaliação da atividade antineoplásica de Annona muricata L.

Paulo, I. (2016). Estudo químico e biológico de Crescentia cujete L. (BIGNONIACEAE) (Doctoral dissertation, Dissertação (Pós-Graduação em Recursos Naturais do Semiárido)-Universidade Federal do Vale do São Francisco. Petrolina).

Silva, G. C., de Oliveira, A. M., Machado, J. C. B., Ferreira, M. R. A., de Medeiros, P. L., Soares, L. A. L., \& Napoleão, T. H. (2020). Toxicity assessment of saline extract and lectin-rich fraction from Microgramma vacciniifolia rhizome. Toxicon, 187, 65-74.

Ramos, R. M., Feitosa, J. M., da Silva Lima, V., da Conceição Santos, R., de Oliveira, A. M., Soares, L. A. L., \& da Silva, G. C. (2020). Estudo comparativo da composição fitoquímica, citotoxidade e potencias antioxidante e fotoprotetor da casca e folha de Erythrina velutina. Brazilian Journal of Development, 6(6), $33140-33158$.

Vargas, E. C. D. A. (2017). Interface entre os saberes populares e científicos sobre plantas medicinais: perspectiva da autonomia do cuidado em saúde.

Viana, L. N. (2015). Estudo fitoquímico e avaliação da atividade antioxidante e biológica da espécie Sparattosperma leucanthum (VELL.) Schum, (BIGNONIACEAE).

Villas-Boas, G. R.., de Araújo, F. H. S., Marcelino, J. M., Castro, L. H. A., da Silveira, A. P. S., Nacer, R. S., ... \& Oesterreich, S. A. (2018). Preclinical safety evaluation of the ethanolic extract from Campomanesia pubescens (Mart. ex DC.) O. BERG (guavira) fruits: analysis of genotoxicity and clastogenic effects. Food \& function, 9(7), 3707-3717. 